\title{
DETECTING CITRUS HUANGLONGBING IN BRAZILIAN ORCHARDS USING HYPERSPECTRAL AERIAL IMAGES
}

\author{
É. A. S. Moriya ${ }^{1}$, N. N. Imai ${ }^{1}$, A. M. G. Tommaselli ${ }^{1}$, A. Berveglieri ${ }^{1}$, E. Honkavaara ${ }^{2}$, M. A. Soares ${ }^{3}$, M. Marino ${ }^{3}$ \\ ${ }^{1}$ Dept. of Cartography, São Paulo State University (UNESP), Presidente Prudente-SP, Brazil (erikaasaito, \\ adilsonberveg)@gmail.com, (n.imai, a.tommaselli)@unesp.br \\ ${ }^{2}$ Finnish Geodetic Inst., Masala, Finland (eija.honkavaara@fgi.fi) \\ ${ }^{3}$ Agroterenas, Santa Cruz do Rio Pardo-SP, Brazil (marcio.sorares, marcelo.marino)@agroterenas.com.br)
}

Commission III, WG III/4

KEY WORDS: Citrus Greening, Remote Sensing, Precision Agriculture, Health Map.

\begin{abstract}
:
Brazil is one of the world leaders in citrus plantation, and the production of orange juice is economically important in the export scenario, being regarded as a fundamental agricultural commodity in Brazil. The worst citrus disease is Greening, or Huanglongbing (HLB), a bacterial disease which cannot be cured and to which no plant variety is immune or resistant. Currently, control of HLB is through the inspection of orchards and the immediate elimination of plants displaying HLB symptoms, plus chemical or biological control of the insect vector (psyllid). The HLB disease has high economic impact on Brazilian and world citriculture, due to the extreme damage to crops. Based on remote sensing techniques, the mapping of diseased and healthy citrus plants from hyperspectral images was carried out, generating a product that could help in the monitoring and control of HLB in Brazilian citrus orchards. The methodology to produce a health map goes through the following stages: aerial image acquisition, radiometric field measurements, hyperspectral cube orientation, and data analysis for detection of HLB in citrus. The field survey was performed in Guacho FarmBrazil and hyperspectral images were acquired by a Rikola camera onboard a light aircraft, obtaining images with $0.50 \mathrm{~m}$ of Ground Sample Distance (GSD). The hyperspectral cubes were classified with Spectral Angle Mapper (SAM) algorithm to produce the health map. Plants infected with HLB were detected with an accuracy $61.2 \%$, the validation of the health map was verified by samples were analysed in the laboratory to confirm HLB.
\end{abstract}

\section{INTRODUCTION}

The technological innovations from Precision Agriculture have contributed to agronomic development by optimizing and automating the processes involved in agriculture, leading to benefits in agricultural production and to the environment (Zhang et al., 2002).

Brazil is a world leader in the production and export of various agricultural products, being the main producer of citrus, in particular, of orange juice. Phytosanitary control of crops is fundamental to the maintenance of quality in agricultural production.

The world's citrus disease is greening (Fundecitrus, 2009), however, officially named Huanglongbing (HLB), Chinese "yellow dragon disease" (Feichtenberg et al., 2005). The first sign of the disease was recorded in southern China in 1919 (Bové, 2006); in Brazil, HLB was found in 2004. The insect vector of the disease is a psyllid Diaphororina citri which transmits the bacteria (Fundecitrus, 2009). The bacterium can be of three species Candidatus Liberibacter asiaticus, Candidatus Liberibacter africanus and Candidatus Liberibacter americanus (Jagoueix et al., 1994; Teixeira et al., 2005).

The importance of HLB lies is in the fact that there is no resistant or immune plant variety. Infected plants become rapidly unproductive and significantly increase the cost of production because of vector control with the use of insecticides or traps (Feichtenberg et al., 2005). HLB is a disease with great economic impact on Brazilian and world agriculture, due to its high damage power and the resultant crop failure.

The current form of control of the HLB is the inspection of orchards and the immediate elimination of plants with HLB symptoms. The chemical or biological control is also performed as a measure to contain the transmitting vector of the HLBcausing bacterium, in this case the psilid Diaphororina citri (Girardi et al., 2011). However, controlled use of pesticides is regarded as being of great importance, particularly because of the risk of contamination of humans, soil and the environment.

The monitoring of citrus diseases and their identification in the first stages are fundamental to guarantee the efficiency of chemical control, and a survey of crops should be carried out frequently. Monitoring through the use of images is a potential tool for mapping diseases in agricultural crops.

Significant changes in crop spectral response due to nutrient deficiency and the presence of weeds in the plantation can be detected by using of hyperspectral images, as demonstrated by Goel et al. (2003) in their research involving corn crops.

Goel et al. (2003), obtained hyperespectral images with the CASI sensor (Compact Airbone Spectrographic Imager) configured with 72 bands of $409 \mathrm{~nm}$ at $947 \mathrm{~nm}$. They applied radiometric, geometric and atmospheric corrections to their images to obtain reflectance values, and analysed the spectral curves extracted from the images.

Hyperspectral data obtained by spectrometers with field or laboratory measurements have also been used in the diagnosis 
of diseases in agriculture, where methodologies are based on the spectral properties of the plant to discriminate diseased plants (Sirisomboon et al., 2009, Jin et al. 2013, Yuan et al., 2013). Identification of diseased plants is important in monitoring a crop's phytosanitary condition and the definition of adequate management to control the disease. Remote sensing technique for detecting disease and stress factors in plants were evaluated.

Abdulridha et al. (2019) developed a low-cost multispectral imaging sensor to detect laurel wilt disease in avocado trees based on artificial neural network classification. The classification method accuracy detected the disease with $99 \%$ of accuracy in asymptomatic stage. Salgadoe et al. (2018) quantified the severity of Phytophthora root rot disease in avocado trees using satellite images analysis to produce a disease severity map. Albétis et al. (2017) evaluated the feasibility of discriminating the Flavescence dorée grapevine disease using potential variables computed from multispectral images.

The combination of multispectral images (GSD $0.5 \mathrm{~m}$ ) and hyperspectral (GSD $0.7 \mathrm{~m}$ ) airborne images with hyperspectral measurements performed in the field and laboratory can provide even more refined data to identify changes due to disease in agriculture, as, for example, in the citrus crop presented by Li et al. (2012), which identified areas infected by HLB. Li et al. (2012) also used different classification methods. Their results were more stable with classifiers based on minimum distance and Mahalanobis distance and it is believed that using terrestrial truth information in the training of classifiers can contribute to a faster detection process.

Remote sensing and photogrammetry products are presented as a potential tool in precision agriculture applications, encouraging the development of new methodological approaches that produce good spatial information to assist farmers in agricultural production planning and decisions.

In this context, a feasibility study was carried out based on remote sensing techniques, aiming at mapping diseased and healthy plants from hyperspectral images, generating a product that assists in the monitoring and control of HLB in citrus in Brazilian orchards. The methodological approach involved aerial survey with field support, radiometric measurements, image processing and analysis of data collected for the detection of HLB in orange trees in Brazilian orchards.

The maps generated enabled the location of diseased plants within the field, and the removal of the diseased plant from the orchard. If the image detected some type of alteration in the plant, some appropriate management measures can be adopted to correct the problem.

\section{METHODOLOGY}

\subsection{Hyperspectral cube acquisition and radiometric measuring}

The study area was located at Fazenda Guacho in the municipality of Santa Cruz do Rio Pardo-SP, Brazil ( $22^{\circ} 47^{\prime} 37.27$ "S and $\left.49^{\circ} 23^{\prime} 42.55^{\prime \prime} \mathrm{W}\right)$. The test area selected was plot 01 of zone 275 that has an area of 15.26 hectares.
The variety of orange planted in this field was "Natal" with a transplantation of "Limão Cravo", with mature plants aged 22 years (planted in January 1997). The row spacing of the plots was about $3.8 \times 7.5 \mathrm{~m}$. The field had about 4777 orange trees. The field borders a pasture area and a road that connects the Castelo Branco Highway to the municipality of Óleo.

The field survey was carried out in the study area and images with a GSD of $0.50 \mathrm{~m}$ were acquired. A Rikola hyperspectral camera model DT-0014 (Figure1.a) was used with a FabryPérot interferometer (FPI), which has the capacity to acquire images in the spectral range of 500 to $900 \mathrm{~nm}$ and can obtain up to 25 spectral bands. The camera bands can be configured automatically or manually (Senop Ltda, 2014). The flight was performed in April 2018 with a light aircraft with a flight hight of $800 \mathrm{~m}$. Table 1 shows the image specifications.

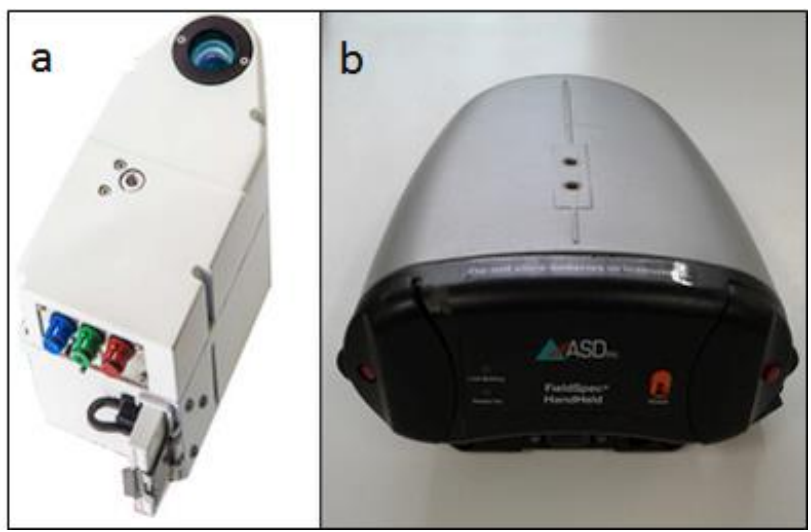

Figure 1. (a) Hyperspectral camera. (b) Espectrometer.

Table 1: Image specifications

\begin{tabular}{|l|l|}
\hline GSD $(\mathrm{m})$ & 0.50 \\
\hline Images number & 100 \\
\hline Flight Height $(\mathrm{m})$ & 800 \\
\hline Flight area $\left(\mathrm{m}^{2}\right)$ & 4211162 \\
\hline Image size (linesxcolumn) & $4190 \times 3640$ \\
\hline
\end{tabular}

Targets assembled with Ethylene Vinyl Acetate (EVA) for radiometric correction were distributed in the field for the acquisition of images. Light gray, dark gray and black tone targets (Figure 2a) were used as reference materials, and their reflectance were measured with a spectrometer (Figure 1.b). The spectrometer model was the FieldSpec HandHeld® UV / NIR ASD, which collects spectra in the spectral range from $325 \mathrm{~nm}$ to $1075 \mathrm{~nm}$ with a sampling range of $1.6 \mathrm{~nm}$ (ASD, 2003). This equipment is portable having a $25^{\circ}$ field of view (FOV), and filters allowing FOVs of $1^{\circ}$ and $10^{\circ}$, the last angle was adopted in this work.

Limestone targets (Figure 2.b) were distributed in the study area for the geometry correction in the phototriangulation process. These targets were surveyed with a double frequency GNSS (Global Navigation Satellyte System). 


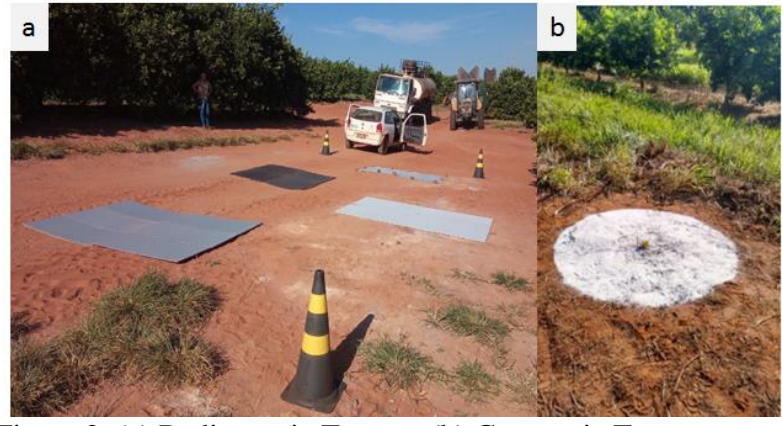

Figure 2. (a) Radiometric Targets. (b) Geometric Targets.

During the images acquisition a spectrometer was used to gather radiometric measurements in the orange orchards to obtain the spectral curves of the healthy oranges and those infected with HLB. With the spectral curves measured in the field, a spectral library was constructed to serve as reference in the procedures of radiometric correction and images classification. Figure 3 shows examples of healthy orange and those infected with HLB.

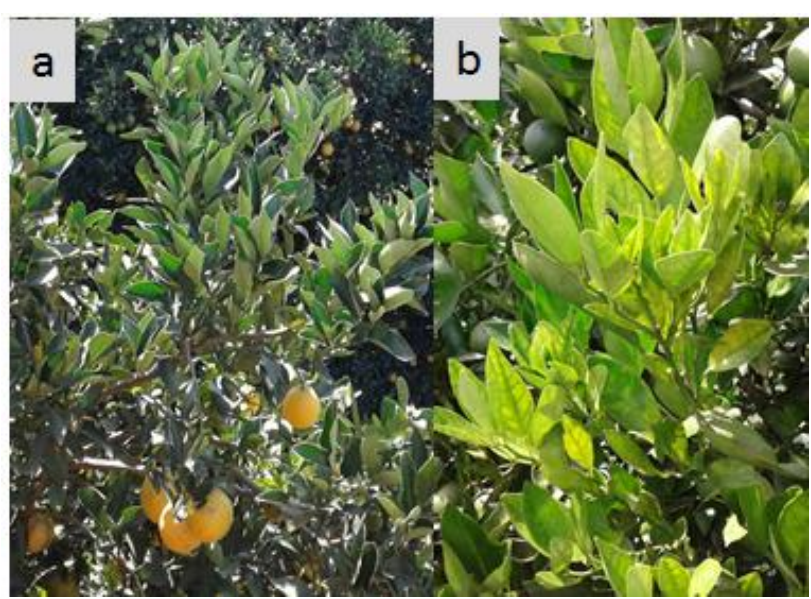

Figure 3. (a) Healthy orange. (b) Orange with HLB.

\subsection{Hyperspectral Cube Processing}

Figure 4 shows the flowchart of steps that summarize the hyperspectral cube processing. Each step will be later presented in details. The hyperspectral cube underwent the Dark Current correction process, using a dark target to eliminate noise from the camera electronics. With the geometric calibration data and the initial coordinates of the GNSS receiver, four bands were selected for phototriangulation using the Agisoft Photoscan software based on the Bundle block adjustment method.

The process of radiometric correction of the hyperspectral images was carried out using software developed by Honkavaara (2013) in which a transformation is made to a standard acquisition geometry with the consequent minimization of the Bidirectional Reflectance Distribution Function (BRDF). This step was based on the Walthall model (1985) with the normalization of scenes to minimize the effects of illumination variation, as developed by Hakala et al. (2013), producing an orthophotomosaic.

In order to perform this correction, exterior and interior orientation parameters, a Digital Surface Model (MDS) with the same GSD of the $0.50 \mathrm{~m}$ hyperspectral cube, sparse cloud and radiometric correction parameters were used (Honkavaara et al., 2012; 2013). Hence, the generated orthophotos mosaic generated presented the same GSD as the original images.

The hyperspectral images orthophotomosaic were radiometrically adjusted through the empirical line in the ENVI software, using data from the targets considered as radiometric references. Empirical line calibration is a method based on linear regression, which calculates the transformation factors of digital numbers (NDs) into physical units (Smith and Milton, 1999; Sahoo et al., 2013). In this case, the pixels were transformed to Conical Hemispheric Reflectance Factor (FRHC) values based on the spectral reference curves of the spectral library samples obtained in the field, in this case the radiometric targets and a tree infected with HLB.

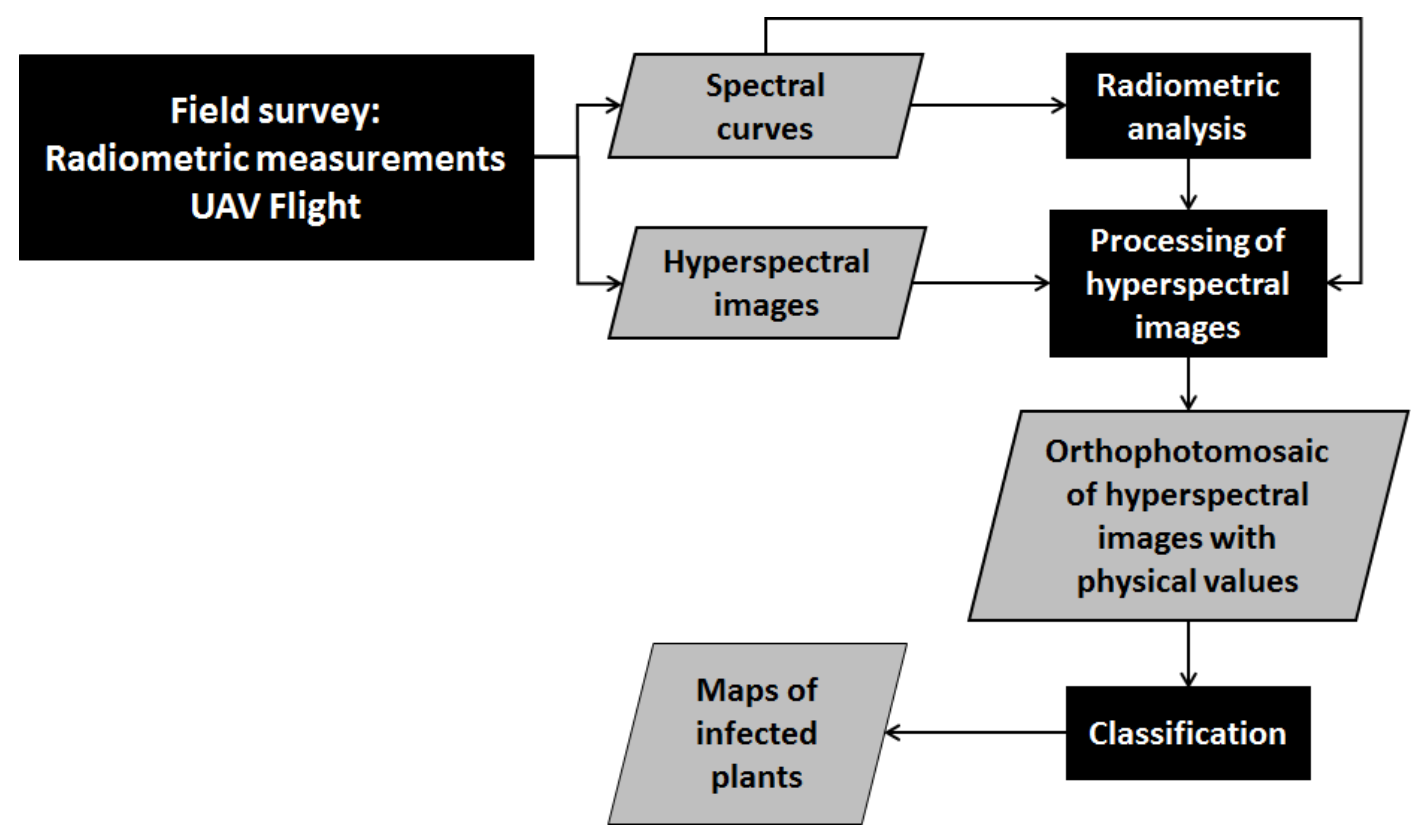

Figure 4. Flowchart of hyperspectral cube processing 


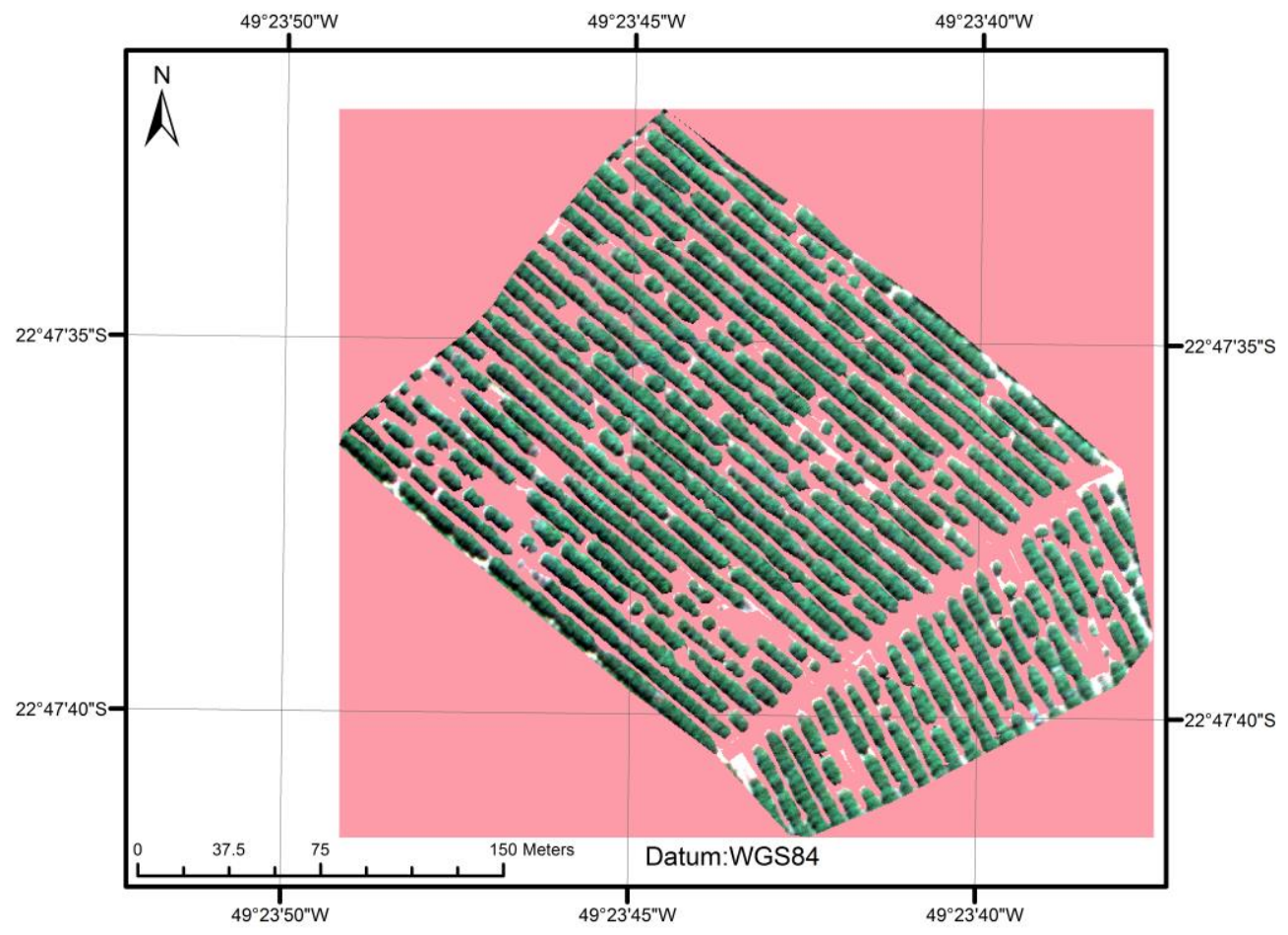

Figure 5. Orthophotomosaic radiometrically corrected.

A procedure was carried out to remove that part corresponding to the streets and spaces between trees presenting weeds, as there was some confusion of the weed class with the plants infected with HLB. The DSM was used to create a mask delimiting the areas that would be removed, keeping only the portion of the tree canopy in the image (Figure 5). A coincident study area was defined, including the survey data and the area overflown, based on the distribution of validation points of the inspection performed by Agroterenas.

After the removal of weed pixels, a Spectral Angle Mapper (SAM) supervised classification algorithm (Kruse et al., 1993) was used to detect HLB infected and healthy plants. The SAM algorithm is based on spectral similarity considering the angle between reference spectra as a parameter to identify the classes (Kruse et al., 1993). Samples were selected from a healthy plant and one infected with HLB. Empirical values were defined for each of the variables considered in the classification.

The results of the classification were validated with plants directly inspected by Agroterenas. Agroterenas carried out three inspections in field 251, in March 2017, in February 2018 and in May 2018. Table 1 shows the number of trees infected with HLB according to the inspections by Agroterenas. Considering that trees infected with HLB were coincident in the three surveys, 175 trees were confirmed with HLB in the technical survey to validate the classification. Figure 6 show the spatial distribution of trees infected with HLB after technical inspection.

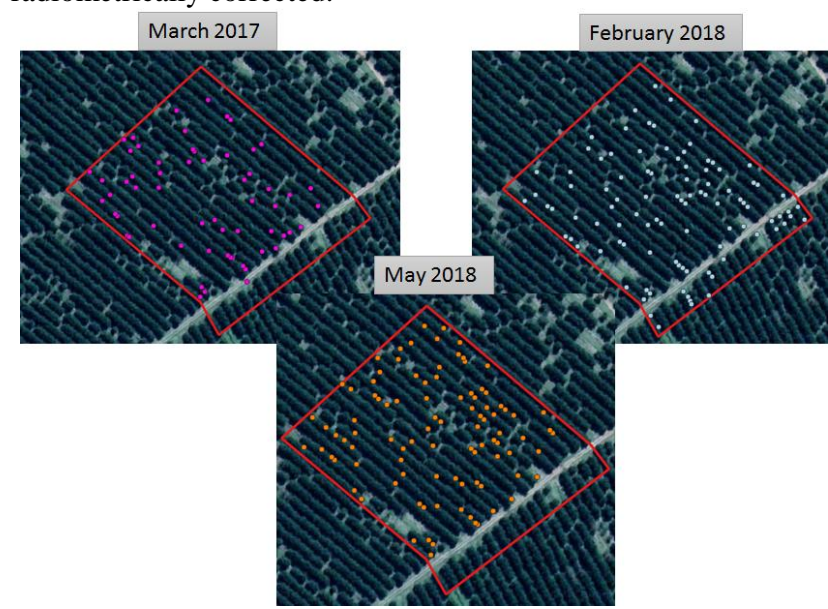

Figure 6. Spatial distribuition of trees deteted with HLB after technical inspection.

\section{RESULTS}

Table 3 presents the error of the geometric parameters of the hyperspectral images in the phototriangulation process.

Table 3: Errors the geometric parameters of the hyperspectral images in the phototriangulation process.

\begin{tabular}{|l|l|l|l|l|l|}
\hline $\begin{array}{l}\text { GSD } \\
\text { Size } \\
(\mathrm{m})\end{array}$ & $\begin{array}{l}\text { X error } \\
(\mathrm{m})\end{array}$ & $\begin{array}{l}\text { Y error } \\
(\mathrm{m})\end{array}$ & $\begin{array}{l}\text { Z error } \\
(\mathrm{m})\end{array}$ & $\begin{array}{l}\text { XY } \\
\text { Error } \\
(\mathrm{m})\end{array}$ & $\begin{array}{l}\text { Total } \\
\text { Error } \\
(\mathrm{m})\end{array}$ \\
\hline 0.50 & 0.36 & 0.45 & 1.02 & 0.57 & 1.17 \\
\hline
\end{tabular}

Orthophotomosaic were generated, with the processing of the hyperspectral cube radiometrically corrected. From the 175 HLB-infected trees inspected by the technicians, the plants classified from the hyperspectral images (Figure 7) presented an accuracy $61.62 \%$ in the detection. Considering the total of 696 trees in the validation area, 83 trees were detected with HLB correctly, and 344 healthy trees were detected correctly. 
However, there were 96 false negatives and 170 plants detected as false positives. False positives correspond to plants classified with HLB but that were not confirmed by the technical inspection. The high presence of false positives is due to the presence of weeds, saturation of the image, asymptomatic plants and confusion of the classifier. Kumar et al. (2012) and Li et al.
(2015) obtained an approximate accuracy of $60 \%$ when using the Sam algorithm to classify Valencia and Hamlin oranges with HLB using hyperspectral images in Florida, this shows the consistency of results is Brazilian orchards.

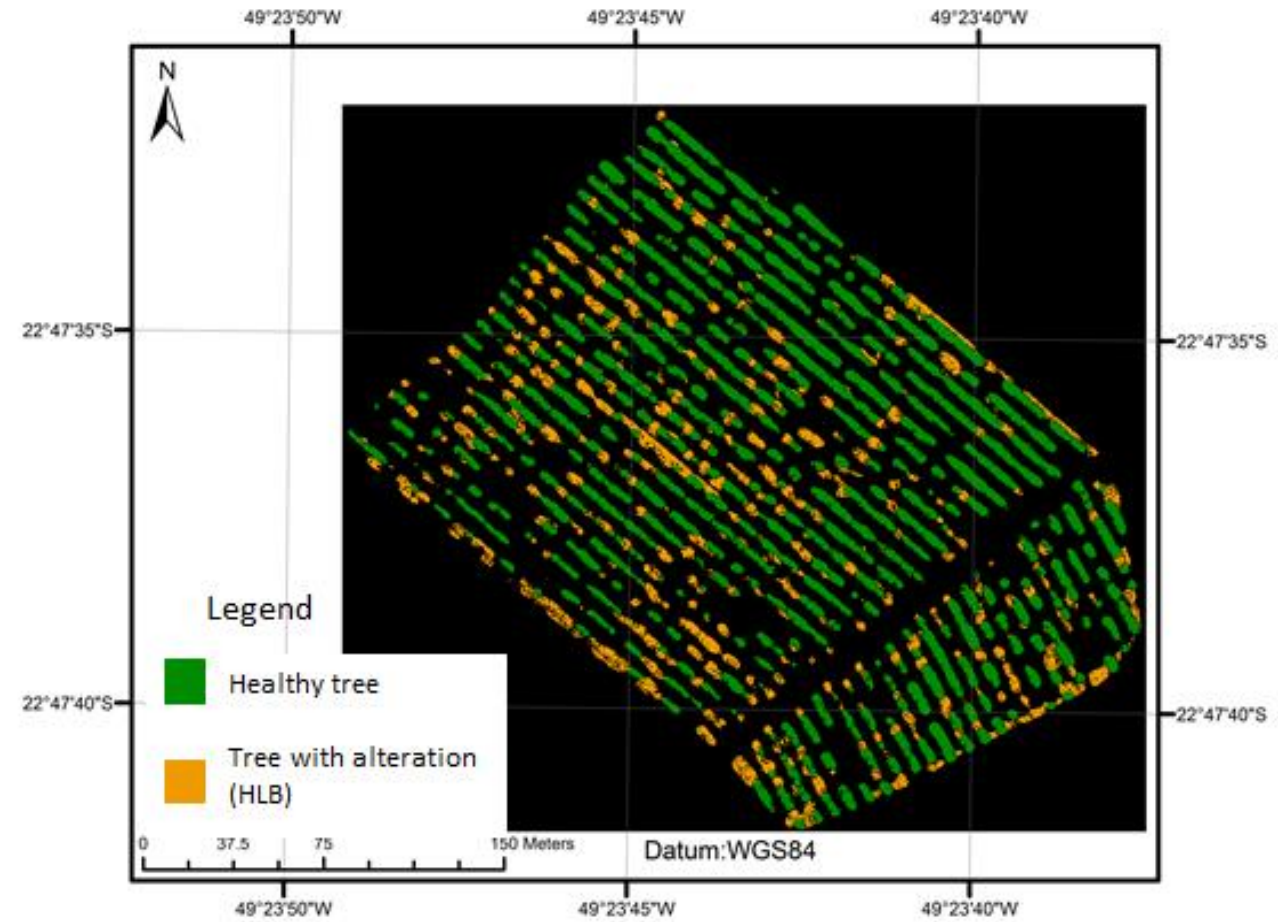

Figure 7. Citrus health map.

\section{CONCLUSION}

In this work was produced a health map goes through the following aerial image acquisition, radiometric field measurements, hyperspectral cube orientation, and data analysis for detection of HLB in citrus.

Hyperspectral images were generally of good quality, with no apparent variations in illumination due to clouds that could interfere with the processes that followed. The application of the calibration by empirical line produced data with Conical Hemispheric Reflectance Factor values.

Accuracy in the detection of HLB was $61.2 \%$ for GSD of 0.50 $\mathrm{m}$. The high detection of false positives is a challenging factor in the differentiation of plants with HLB. The hypothesis is that the presence of weeds at the edge of the tree caused confusion of the classifier in differentiating the plants infected by HLB. The saturation of the image and the presence of shadows caused by the citrus canopy architecture itself, are factors that contributed to the high number of false positives. All these factors should be better evaluated and more thoroughly and more efficient automatic processing solutions should be explored.

The innovations of precision agriculture open possibilities to facilitate the activities developed by the farmer, improve agricultural production, reduce environmental impact and, mainly, contribute to the development of more sustainable agriculture in Brazil.

\section{ACKNOWLEDGEMENTS}

The authors are thankful to The National Research Council $(\mathrm{CNPq})$ for Pos-Doctoral Scholarship and Foundation for Unesp development (Fundunesp), Agroterenas Citros, Branco Peres Agribusiness, Cambuhy Agrícola, Citrosuco, Faro Capital Agribusiness, for funding this research. Special thankful to Agroterenas Citros, in Santa Cruz do Rio Pardo for their important support in the collection of radiometric measurements in the field.

\section{REFERENCES}

Abdurridha, J., Ehsani, R; Abd-Elrahman, A.; Ampatzidis, Y. 2019, A remote sensing technique for detection laurel wilt disease in avocado in presence of other biotic and abiotic stresses. Computer and Electronics in Agriculture 156, pp.549557.

Albetis, J.; Duthoit, S.; Guttler, F.; Jacquin, A.; Goulard, M.; Poilvé, H.; Féret, J-B; Dedieu, G. 2017. Detection of Flavescence dorée grapevine disease using unmanned aerial vehicle (UAV) multispectral imagery. Remote Sensing 9, pp.120.

ASD, 2003. FieldSpec®UV/VNIR: HandHeld Spectroradiometer. User's Guide, pp.72.

Bové, J. M., 2006. Huanglonbing: a destructive, newlyemerging, century-old disease of citrus. Journal of plant pathology 88 (1), pp. 7-37. 
Feichtenberg, E.; Bassanezi, R. B.; Spósito, M. B.; Belasque Jr.; J. Doenças dos citros. In: Kimati, H.; Amorim, L.; Rezende, J. A. M.; Bergamin Filho, A.; Camargo, L. E. A., 2005. Manual de Fitopatologia: doenças das plantas cultivadas. São Paulo: Ceres 2, pp. 663. (ISBN 85-318.0043-9) (In portuguese)

FUNDECITRUS- Fundo de Defesa da Citricultura, 2009. Manual técnico: Greening,pp. 12. (In portuguese)

Girardi, E. A.; Nascimento, A. S.; Laranjeira, F. F.; Andrade, E. C. V.; Freitas-Astúa, J. ; Barbosa, C. J.; Sanches, N. F.; Stuchi, E. S.; Fancelli, M.; Santos Filho, H. P.; Oliveira, A. A. A., 2011. Guia de identificação do Huanglogbing (HLB, Exgreening). Cruz das Almas: EMBRAPA- Mandioca e Fruticultura, pp.34. (In portuguese)

Goel, P. K.; Prasher, S. O.; Landry, J. A.; Patel, R. M.; Bonnell, R. B.; Miller, J. R., 2003. Potencial of airbone hyperspectral remote sensing to detect nitrogen deficiency and weed infestation in corn. Computers and Electronics in Agriculture 38, pp. 99-124.

Hakala, T.; Honkavaara, E.; Saari, H.; Mäkynen, J.; Kaivosoja, J.; Pesonen, L.; Pölönen, I., 2013. Spectral imaging from UAVS varying illumination conditions. In: International archives of the Photogrammetry, remote sensing and spatial information sciences, v. XL-1/W2, 2013 UAV-g2013, 4-6 september 2013, Rostock, pp. 189-194.

Honkavaara, E.; Kaivosoja, J.; Mäkynen, J.; Pellikka, I.; Pesonen, L.; Saari, H.; Salo, H.; Hakala, T.; Markelin, L.; Rosnell, T., 2012. Hyperspectral reflectance signatures and point clouds for precision agriculture by light weight UAV imaging system. In: ISPRS Annals of the Photogrammetry, Remote Sensing and Spatial Sciences, v. I-7, 2012, XXII ISPRS Congress, 25 august-01 september 2012, Melbourne, pp.353358.

Honkavaara, E.; Saari, H.; Kaivosoja, J.; Pölönen, I.; Hakala, T.; Litkey, P.; Mäkynen, J.; Pesonen, L., 2013. Processing and assessmet of spectrometric, stereoscopic imagery collected using a lightweight UAV Spectral Camera for Precision Agriculture. Remote Sensing 5, pp. 5006-5039.

INSTITUTO NACIONAL DE METEOROLOGIA (INMET). Dados de estações automáticas. Disponible in: <http://www.inmet.gov.br/portal/index.php?r=estacoes/estacoes Automaticas>. Acessed: November 2017. (In portuguese)

Jagoueix, S.; Bove, J. M.; Garnier, M., 1994. The phloemlimited bacterium of greening disease of citrus is a member of the $\alpha$ subdivision of the proteobacteria. International Journal of Systematic Bacteriology 44(3), pp. 379-386.

Jin, N.; Huang, W.; Ren, Y.; Luo, J.; Wu, Y.; Jing, Y.; Wang, D., 2013. Hyperspectral identification of cotton verticillium disease severity. Optik 124, pp. 2569-2573.

Li, X.; Lee, W. S.; LI, M.; Ehsani, R. Mishra, A. R.; Yang, C.; Mangan, R. L., 2012. Spectral difference analysis and airbone imaging classification for citrus greening infected trees. Computers and Electronics in Agriculture 83, pp. 32-46.

Li, X.; Lee, W. S.; Li, M.; Ehsani, R.; Mishra, A.; Yang, C.; Mangan, R. L., 2015. Feasibility study on Huanglongbing (citrus greening) detection based on WorldView-2 satellite imagery. Biosystems engineering 132, pp. 28-38.

Kumar, A., Lee, W. S., Ehsani, R. J., Albrigo, L. G., Yang, C., Mangan, R. L., 2012. Citrus greening disease detection using aerial hyperspectral and multispectral imaging techniques. Journal of Applied Remote Sensing 6, pp. 22.

Kruse, F. A., A. B. Lefkoff, J. B. Boardman, K. B. Heidebrecht, A. T. Shapiro, P. J. Barloon, and A. F. H. Goetz., 1993. The Spectral Image Processing System (SIPS) - Interactive Visualization and Analysis of Imaging spectrometer Data. Remote Sensing of Environment 44, pp. 145-163.

Salgadoe, A. S. A.; Robson, A. J.; Lamb, D. W.; Dann, E. K.; Searle, C. 2018. Quantifying the severity of Phytophthora root ro disease in avocado trees using image analysis. Remote Sensing 10, pp.1-17.

Sirisomboon, P; Hashimoto, Y.; Tanaka, M., 2009. Study on non-destructive evaluation methods for defect. Pods for green soybean processing by near-infrared spectroscopy. Journal of food engineering 93, pp. 502-512.

Smith, G. M.; Milton, E. J. 1999. The use of the empirical line method to calibrate remotely sensed data to reflectance. International Journal of Remote Sensing 20 (13), pp.26532662.

Teixeira, D. C.; Danet, J. L.; Eveillard, S.; Martins, E. C.; Jesus JR.; W. C.; Yamamoto, P. T.; Lopes, A. S.; Bassanezi, R. B.; Ayres, A. J.; Saillard, C.; Bové, J. M. 2005. Citrus huanglongbing in São Paulo State, Brazil: PCR detection of the 'candidatus' Liberibacter species associated with the disease. Molecular and Cellular Probes19, pp. 173-179.

Yuan, L.; Zhang, J-C.; Wang, K.; Loraamm, R-W.; Huang, WJ.; Wang, J-H.; Zhao, J-L. 2013. Analysis of spectral difference between the foreside and backside of leaves in yellow rust disease detection for winter wheat. Precision Agriculture 14, pp. 495-511.

Walthall, C.L.; Norman, J.M.; Welles, J.M.; Campbell, G.; Blad, B.L., 1985. Simple equation to approximate the bidirectional reflectance from vegetative canopies and bare soil surfaces. Applied Optics 24, pp. 383-387.

Zhang, N.; Wang, M.; Wang, N. 2002. Precision agriculture: a worldwide overview. Computers and electronics in agriculture 36, pp.113-132 